Рад примљен: 27. 9. 2021.

Рад прихваћен: 22. 11. 2021.

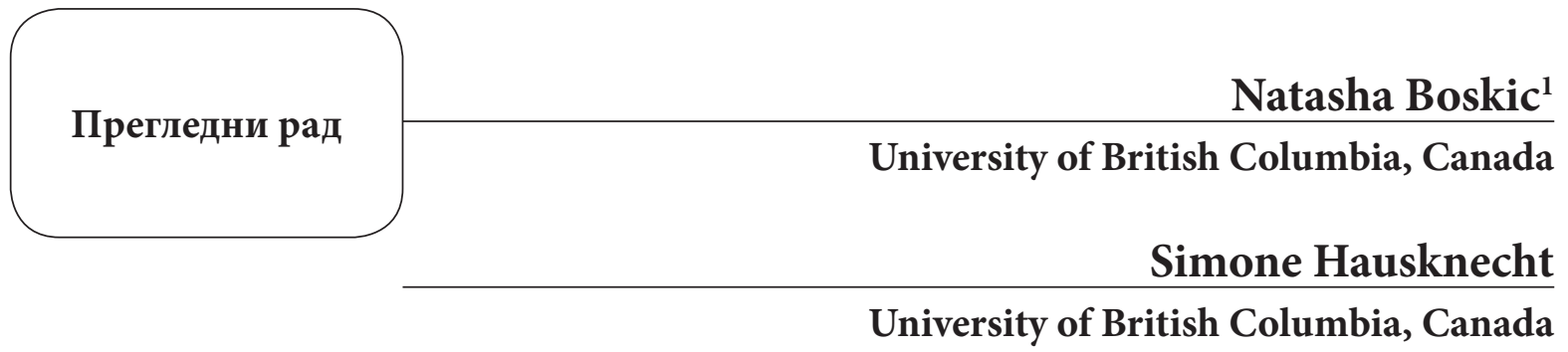

\title{
Reshaping the educational landscape: During and after the COVID19 pandemic
}

\begin{abstract}
Summary: The aim of this paper is to describe and analyze the response to COVID-19 and evolution through different models of online instruction during the pandemic at a large Canadian university. This paper primarily focuses on the approach taken by the Faculty of Education including the necessary restructuring of the processes, organization of the workforce, support configurations, and institutional constraints. The factors that impacted changes in the curriculum are examined. Three distinct phases were identified and compared: 1) remote teaching, 2) fully online using a combination of synchronous and asynchronous instruction, and 3) a diversity of hybrid approaches. The paper highlights a number of challenges experienced with online education during the pandemic. Each one of them presents both barriers and opportunities. The process has made way for a potential transformation of educational practice at North American universities. This will likely come as a combination of increased knowledge and practice of online learning during the pandemic, and as a need to reshape traditional institutional structures to reflect the shifted landscape of education. It has opened discussions on equity and accessibility, learner-centered design, and the potential for change in the classroom and educational programming.
\end{abstract}

Keywords: Online learning, educational technology, learning design, pandemic, organizational change, support.

1 natasha.boskic@ubc.ca

Copyright (c) 2021 by the authors, licensee Teacher Education Faculty University of Belgrade, SERBIA.

This is an open access article distributed under the terms of the Creative Commons Attribution License (CC BY 4.0) (https://creativecommons.org/licenses/by/4.0/), which permits unrestricted use, distribution, and reproduction in any medium, provided the original paper is accurately cited. 


\section{Introduction}

In 2020, many universities were required to quickly move into remote teaching due to the COVID-19 pandemic. The shock of the events was followed by an attempt to buffer damage by rapidly replacing in-person teaching with an online classroom (Bryson \& Andres, 2020). Some universities were better prepared and had systems in place to support online teaching and learning while others struggled due to a lack of support, infrastructure, or political ideologies resistant to online or blended learning (Ali, 2020). Most instructors had to change their teaching approach to meet student needs (Núñez \& Leeuwner, 2020). These came with both positive and negative experiences (Adedoyin \& Soykan, 2020; Walsh et al., 2021). According to UNESCO's report on the impact of COVID -19 on higher education institutions, the disruption of education "affected more than 220 million tertiary-level students around the world" (UNESCO, 2021, p.1). As the pandemic continued, many institutions remained online for over a year. This created a situation for ongoing adjustments and development of online classrooms.

The University of British Columbia (UBC), with twelve Faculties, is one of the world's top research universities, attracting more than $\$ 650$ million in research funding each year (UBC, 2021). Its Faculty of Education (FoE) is the largest Faculty of Education in the province of British Columbia and ranks within the top 10 faculties in the world. It consists of six academic units, a number of administrative and support offices, as well as different centres and institutes. The two major groups of student population are those studying in the BEd program (obtaining their Teaching certificate), and those in a variety of graduate programs (diplomas, master or doctoral studies). In both cases, the students are those who are preparing to teach or educational practitioners already in the field. With scholars who have the highest success rate at UBC in applying for research grants, FoE is a considerable contributor to the research activity.

During the first half of the pandemic year, there was a pause in research field work due to the fact that it was primarily being done with human subjects. This forced the FoE leadership to re-think faculty members' daily life and their engagement. The leadership team was committed to the promise that no full-time employee or tenure-track faculty member would lose his/her job due to the pandemic, similar to the majority of countries in Europe and North America. According to the UNESCO's survey (2021), eighteen out of twenty-seven countries reported no reduction in academic and administrative staff employment despite the closure of the universities. Still, some radical shifts had to be made in relation to workloads, appointments, and the teach/research ratio in the time of COVID.

The FoE at UBC has a long history of remote learning, from correspondence courses to the first fully online offerings in 2002. It has established a reputation in the field as a leading Faculty in this area with fully online Master Degree programs offered across Canada and internationally. The main unit responsible for assisting with online delivery in the Faculty is the Educational Technology Support (ETS). The ETS team is a small group of professionals dedicated to the Faculty to provide learning design and educational technology support.

Because of the Faculty's history with online courses, the sudden switch to fully online delivery might have come easier than in the rest of the University, but it did not happen with less effort and investment. Despite the good expertise in-house, the ETS was not able to handle the fourfold number of requests. As the landscape during the pandemic kept changing with every academic term, due to newly obtained knowledge, approaches and skills, the leadership and ETS unit continued to make modifications and accommodations. Three distinctive phases were identified in this journey through the pandemic: 1) remote teaching, 2) fully online 
combination of synchronous and asynchronous instruction, and 3) a diversity of blended models.

\section{Background}

UBC has a long history of using learning management systems (LMS), starting with WebCT, that was created by Murray Goldberg, a faculty member in computer science at UBC, in 1996. All credit courses are automatically created in LMS approximately two weeks after the UBC course calendar has been published. In the Faculty of Education, pre-Covid adoption of today's centrally supported LMS, Canvas, was in the range of $35-40 \%$. Lots of course shells stayed empty. The majority of the ones used were for fully online courses. This relatively low rate was partially a result of the BC Ministry of Education's requirements for all the BEd Teacher Education Certificate courses to be exclusively offered in the classroom. No online or blended instruction was allowed. This resulted in the majority of fully online courses that existed were graduate courses. There was no incentive for the instructors teaching in the BEd program to learn or use educational technology despite the obvious demand in the field. Predominantly, the use of learning technologies was dependent on enthusiasm, interest and personal digital literacy skills of the individual faculty members.

Distance education courses, despite their quality and consistent increase in student enrollment over the years, were not necessarily seen as on par with in-class courses. In alignment with this, teaching online was also not seen as equivalent to in person teaching, so it was mainly left to sessional lecturers. This was not a unique perception of online learning and thus, the requirement for learning digital literacy skills among educational professionals was low. It would be safe to assume that the situation in the FoE and at UBC in general, was similar to other institutions across the globe where the pre-Covid level of digital literacy skills was concerning. According to Times Higher Education report
(2021), that looked into the status in UK, the pandemic's accelerated use of technology exposed the need for a greater level of digital literacy.

The university reacted to the new pandemic situation by enabling financial support from the government. It was left to the individual Faculties to identify their needs and decide on the priorities and where the funds were spent. Some Faculties decided to invest in the recording equipment and tech enhanced classrooms, some in hiring graduate students to help out with content upload into the LMS, Canvas. The Faculty of Education, however, took a unique approach to this challenge and opportunity, and decided to hire five learning designers (part time and fulltime contract positions), all graduates from its own Master Degree in Educational Technology (MET). The strategic idea was to invest in building internal capacity for the future by developing digital literacy skills among all its members, faculty, students and staff. Financially, it was more costly to hire highly educated professionals, than undergraduate student help. This decision was founded in the premise that it was more important to spend time with instructors demonstrating what good online course design was and discussing how it could help improve student learning experience, than to teach them how to upload a file in Canvas or open a discussion forum. As soon as the "Why" was there, the "how" was much easier to accomplish. The assumption was that the focus on the paradigm shift would have long lasting effect. With this specific goal in mind and specific hiring target, FoE was interested in tracking and measuring how successful this approach to the transition of all courses to online would be, and, as a subgoal, how successful the MET program is in producing learning design and educational technology experts.

\section{Aims \\ This paper aims to describe the processes and shifts of an Educational Technology Support unit in assisting faculty to transition to online learning dur-}


ing the COVID-19 pandemic. We set out to answer the questions: In what ways, if any, did the ETS unit adapt to the ongoing needs during the COVID-19 pandemic? From the institutional perspective, what lessons does this teach us for future events?

\section{Methods}

The paper examines and describes the praxis of an educational technology support team during the period between March 2020 to September 2021, from the first lockdown of the University of British Columbia campus in Vancouver, Canada, to the opening of the in-class instruction after 18 months of remote teaching and learning. We take a pragmatic approach to analyzing the shift through different phases of the pandemic and how they led to today's changed reality in the educational landscape. To review the practice of the unit, we examined how the structure changed (based on adjustments to hiring, who was hired, organization of teams) and how it impacted the continuation of instruction. In addition, we analyzed the activities of the unit in relation to the ongoing demands (e. g. emails, workshops, design adjustments to meet the changing challenges). This included the unit's response to student and faculty feedback.

The data was organized into semesters (which make up the phases). These were examined to accurately describe the modifications between the phases and compare the differences. Graphs were created for emails, workshops, and number of courses supported at different points during the pandemic to get a visual representation of the shifts. In addition, the organizational structure of the team was recorded and analyzed to compare the differences from one semester to the next. To explore the findings in depth, the authors also provide the contextual background for the shifts (such as student and staff feedback, funding, and university factors). A narrative approach was adopted for the writing of this paper as its authors' lived experiences as members of the unit (director and learning designer) make valuable contributions to the understanding of the results.

\section{Results}

From the initial pandemic response to moving back to campus, there was a distinct shift between semesters, taking us to a journey from substitution to redefinition of teaching and learning (Puentedura, 2010).

\section{Phase 1: Remote teaching}

When the pandemic and the restrictions on face-to-face gathering began, most instructors were half way through the winter semester (Mid-March), and preparing for summer courses. The easiest way to continue teaching was to move their lectures to an online synchronous session. Many simply took their current program and used a web conferencing system to replicate the way they teach in the classroom. The main system available in the Canvas environment was Collaborate Ultra web conferencing tool. UBC IT made a quick environmental scan and decided to introduce Zoom to its learning technology ecosystem. In record time, the staff members were provisioned with Zoom accounts.

A number of administrative staff that lost some of their duties due to the pandemic, were tasked to help ETS. Most of them were quickly trained to provide basic, tier 1 learning technology assistance. They were paired with experienced learning designers, and then assigned to a number of programmatic units (Departments, Schools, Institutes and similar), which included individual instructors and courses (Fig. 1). The remaining members of the support team were focused on supporting the existing fully online courses and programs developed pre-Covid. ETS staff increased substantially due to the decisions to re-organize the unit and spend the resource funds on contract expertise. It grew from a five-person unit to a team of 15-20 people at different times of the year. 


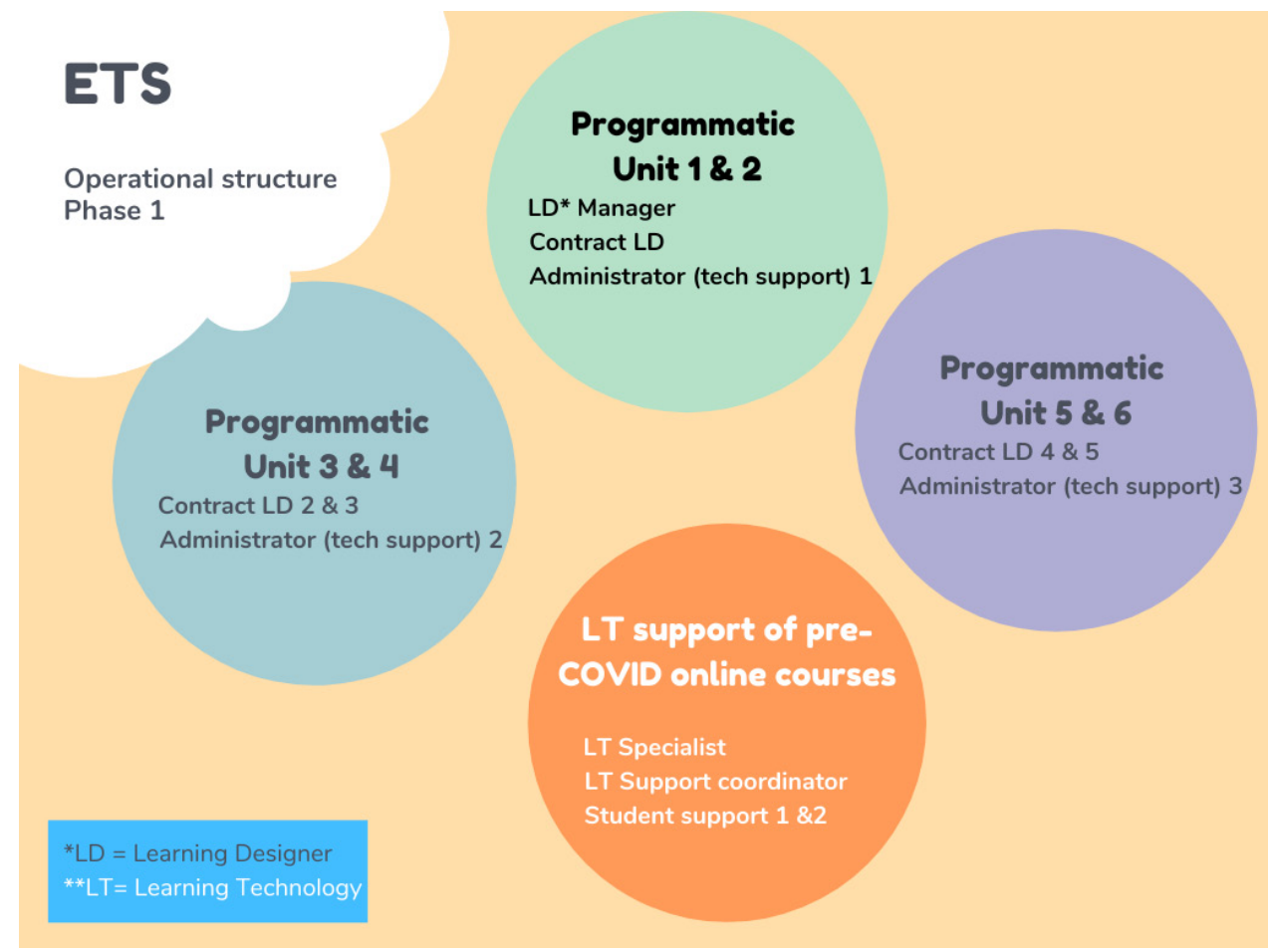

Figure 1. ETS Operational structure in Phase 1

The development of tech skills was accomplished in a number of different ways: by providing ample self-guided instructions (video and text tutorials), by using examples of good course design and good online assessment strategies, by organizing opportunities to learn about tools at workshops and events, but also by strengthening the tech support part of the ETS team. The newly-hired learning designers worked together with the experienced members of the team to provide consultation on pedagogical approaches and online teaching. At the same time, they were introduced to the established processes and had to get accustomed to the culture of the workplace. Learning how to operate in a virtual environment, mastering the functionality of the tools while concurrently meeting the curriculum requirements was very challenging for instructors. The idea that "the way I teach in the classroom, I can just do online" soon proved to be a large misconception. The lack of required digital literacy skills during hiring for teaching positions, and thus neg- lecting those skills, showed to be a weakness in the process of moving to a remote classroom.

The initial invitations for consultations with learning designers were only marginally taken upon. The replication of classroom practice into a synchronous Zoom session, that was the most frequent way of "accelerated migration to online," was a major disaster. The students felt lost and overwhelmed, and they expressed this in their feedback. However, being a new reality for everyone, there was a lot of flexibility and a lot of understanding of each other's mistakes, both on the instructor and student side. We were all learning, and learning quickly.

\section{Phase 2: Evolution to designing for online learning}

Moving into preparation for the winter courses (September 2020 semester) there were a few significant adjustments. Initial student feedback from the remote learning sessions, requested increased asyn- 
chronous activities, less synchronous time, standardization of the environment, online engagement tools with more time allotted for activities, etc. A couple of months into the pandemic, the FoE leadership team provided some strong recommendations:

- The workload of faculty members who ended up with reduced research activities was to be shifted to authoring online courses.

- Adoption and implementation of guidelines for course development, which were based on the criteria that took into account the program enrolments, tuition revenue, the nature of the course (required or elective), the likelihood that the course could be offered online post-covid, the fact that the online version already existed, and so on. The guidelines were to help Departments and Schools look at their courses and their needs differently and prioritize appropriately.

- Each course author was to be connected with a learning designer for support.

- The enhancement of skills and competences of the staff members who temporarily changed their role to be continued, and further adjustments to their tasks be made in order to increase the efficiency of the support provided.

There was a common resolve by the academic and administrative staff to work collaboratively and respond to the challenges of the pandemic in a way that would demonstrate the institutional care for its student's learning. ETS also made changes in its internal organization. After a few months of being frenzied, where the experienced support team spent many hours on training staff from different roles, such as program and administrative assistants and members of the marketing team to become tech support, the challenge of this approach became apparent. Those whose background or interest was not in learning technologies had a very hard time with this partial change of their duties. They were expected to learn in a couple of weeks what others were learning in months or years and this was not viable. The team had to be re-organized again.

Mini-teams were created, where a few learning designers were partnered with strong and experienced learning technologists (LTs) in order to respond to the demands more efficiently. Based on their personal strengths and capacity, the administrative staff members either stayed with the learning technology support team, or their skills were used in a different way, such as support that involved specialized tasks more in line with their personal strengths. For example, a marketing and communication coordinator focused on providing frequent updates on the ETS website that became the centre for critical information. She was in charge of coordinating with LD and LT teams around upcoming professional development offerings, taking care of publishing, administering and promoting the sessions. The student employees served as runners-up, first line responders to the inquiries and requests. They were able to quickly triage the questions between mini-teams and members. They were also tasked with learning and mastering either new tools that UBC IT was provisioning to help with online learning, such as MS Teams, or those that had sudden increase in use, like collaborative or interactive tools, such as H5P (see Fig. 2).

The team meetings turned into internal professional development where experience and issues were shared and new knowledge presented. The use of MatterMost (an open-source online chat service) became a critical life line for communication among ETS team members. The messages were flying from one channel to another, and probably if not more, through private, direct messaging. These replaced casual conversations and provided a space for instant and ongoing communication, including checking on tasks and knowledge exchange. It also enabled the team to be tightly connected and collaborate throughout the day despite the remote locations. 


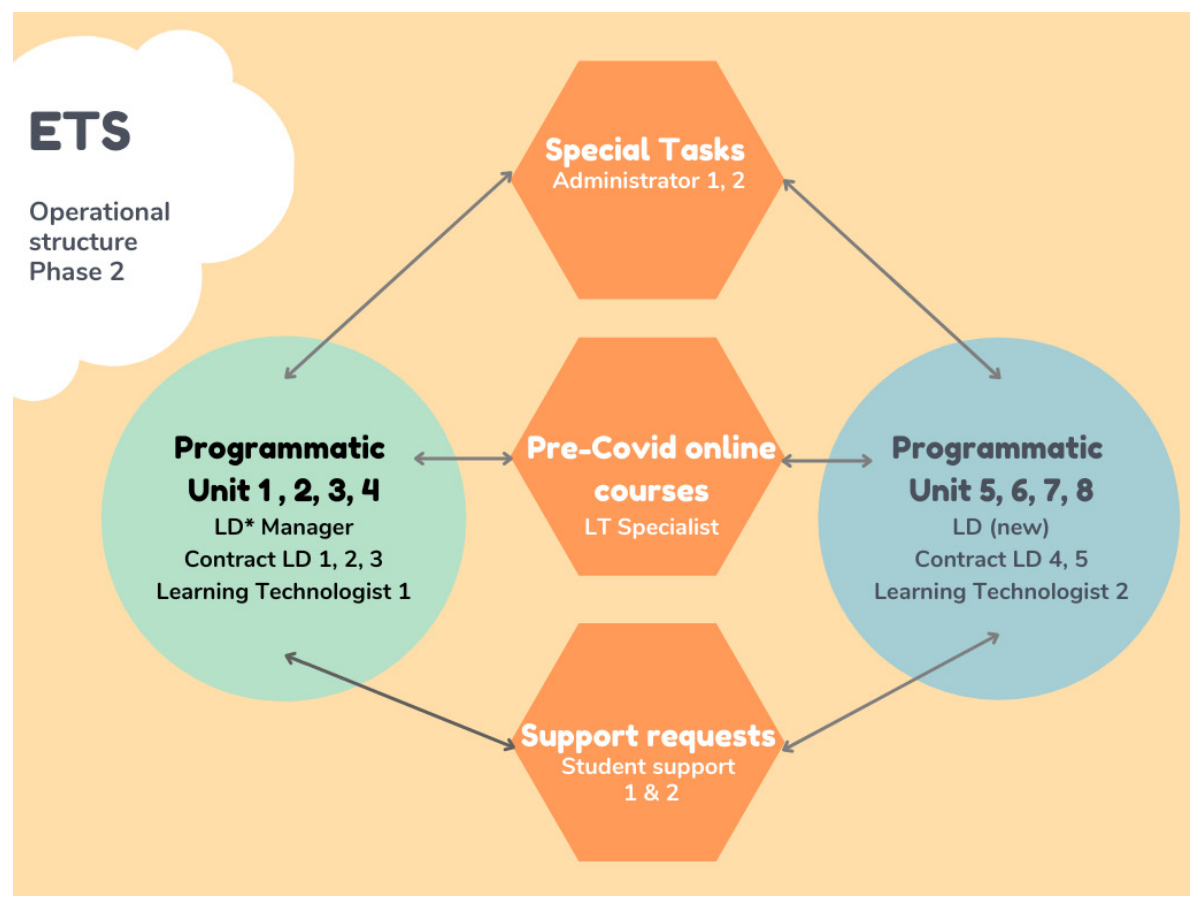

Figure 2. ETS Operational structure in Phase 2

The pandemic seemed to have a longer life than summer 2020 and the promise that everyone would be back in the classrooms by September did not materialize. However, preparation for September looked much better organized and unified. The number of sections for Fall semester (about 400+) still seemed pretty daunting in comparison to the number of learning designers (equivalent to 6 full time employees). A number of strategies were implemented to assist with creating a quick but effective design of the courses that is also conducive to online learning.

A "course starter" was created by the LDs and applied to most sections. This allowed for a basic format that could be adjusted and personalized to the course needs. Each course had a designated learning designer and learning technologist who would work with the course author to create the online course. This involved an initial meeting where the LD could consider the syllabus and discuss the course with the author to understand the unique needs such as the learning outcomes, instructor's digital literacy skills, student needs, and assessments. From an initial conversation and examination of the course syllabus, modules, assignments, activities, and other aspects of the course could be developed. LDs were assigned based on their previous experience working with different Departments and faculty members. This was important as relationship building was found to be one of the most crucial aspects to supporting faculty in developing their online courses and adoption of new approaches. These adjustments led to a more efficient process with courses that could include a variety of online styles. Thus, despite an increase in the number of courses for September term (Fig. 3), the quality of the courses and the process of design and development was improved. As observed in the study by Nworie (2021), this may also be due to faculty members recognizing that they can teach online, and that teaching can be good quality, and in some instances better than in-person. At the same time, there was a general recognition that designing a good online learning experience required time and investment. 


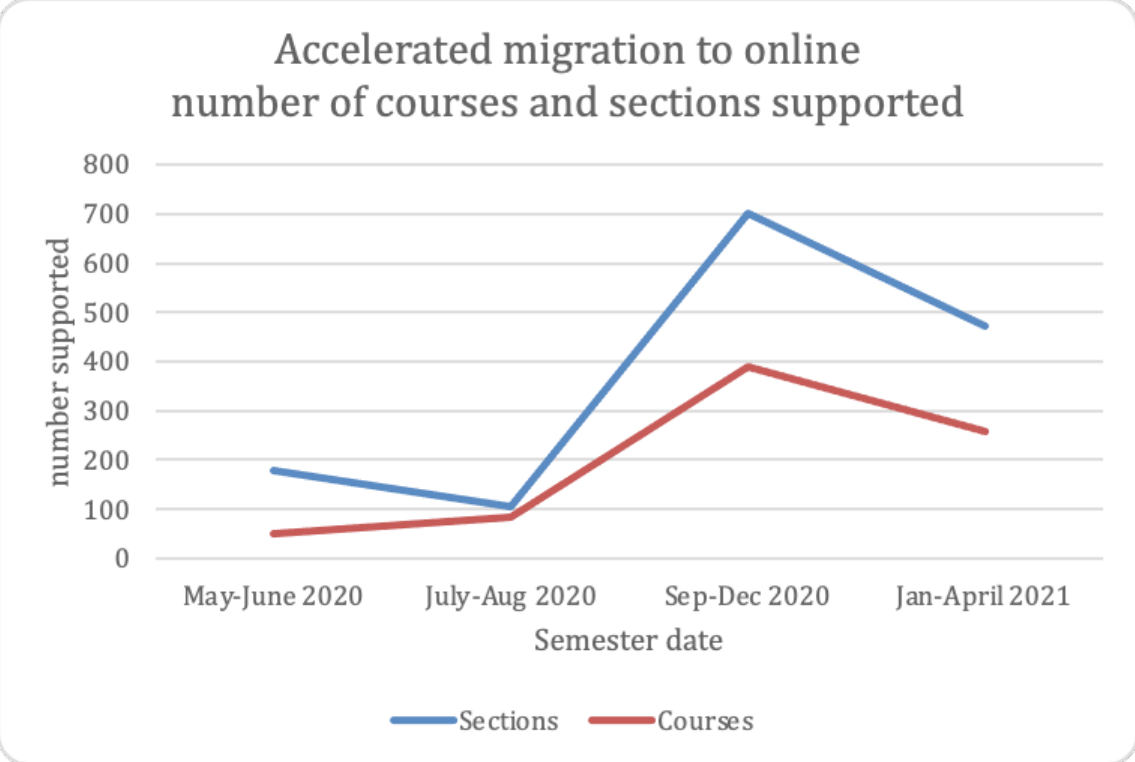

Figure 3. Courses and sections supported over the pandemic

In addition to the one-on-one interactions, LTs also addressed ongoing issues through the common unit email, responding to requests. This became increasingly important as there was a sharp rise in emails from the start of the pandemic and peaking during the start of the winter term (Figure 4).

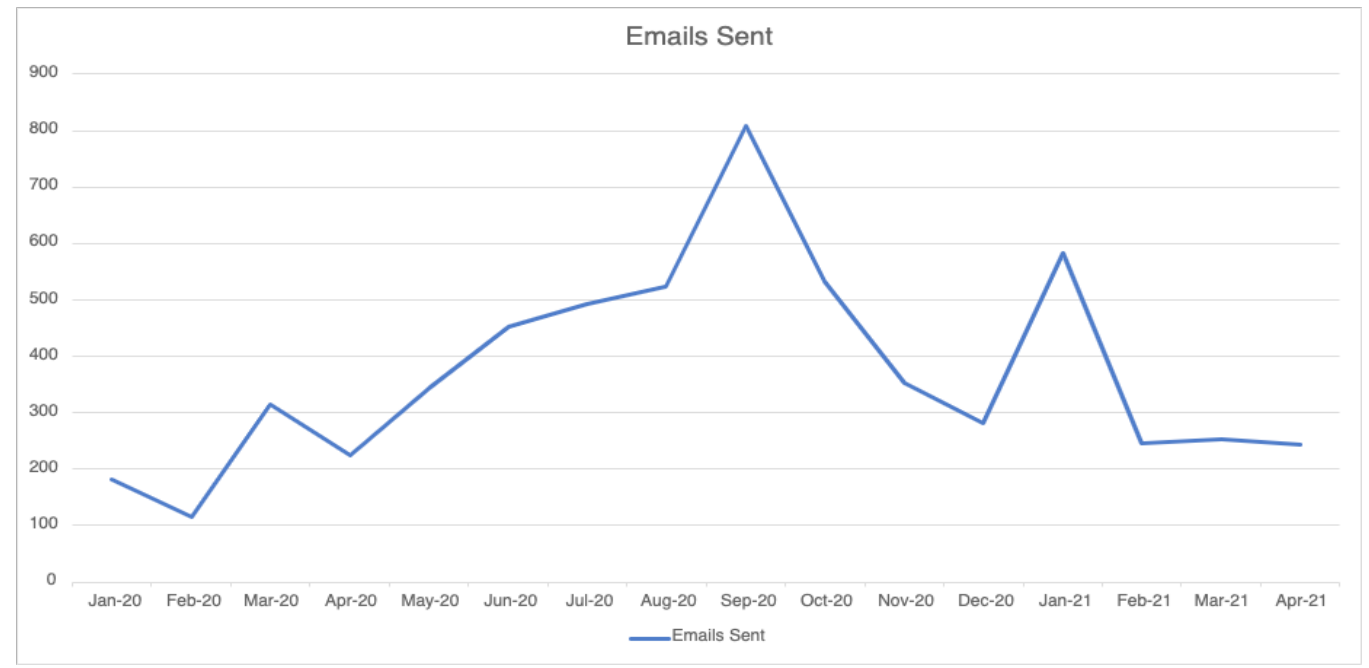

Figure 4. Emails to the ETS Inbox over the pandemic 
Over this time, there was a shift to increasingly more complex requests and a greater consideration for pedagogy. The team began to explore more interactive technologies and designs (such as using $\mathrm{H} 5 \mathrm{P}$ ) and a greater consideration for tools that could enhance collaboration (various peer review technology and multiple options for online discussions and interaction, such as Padlet).
In total, ETS supported almost 700 courses and over 1300 sections from May 2020 to the end of April 2021 as compared to much smaller numbers in the previous year. Over this time most support activities increased extensively (Figure 5).

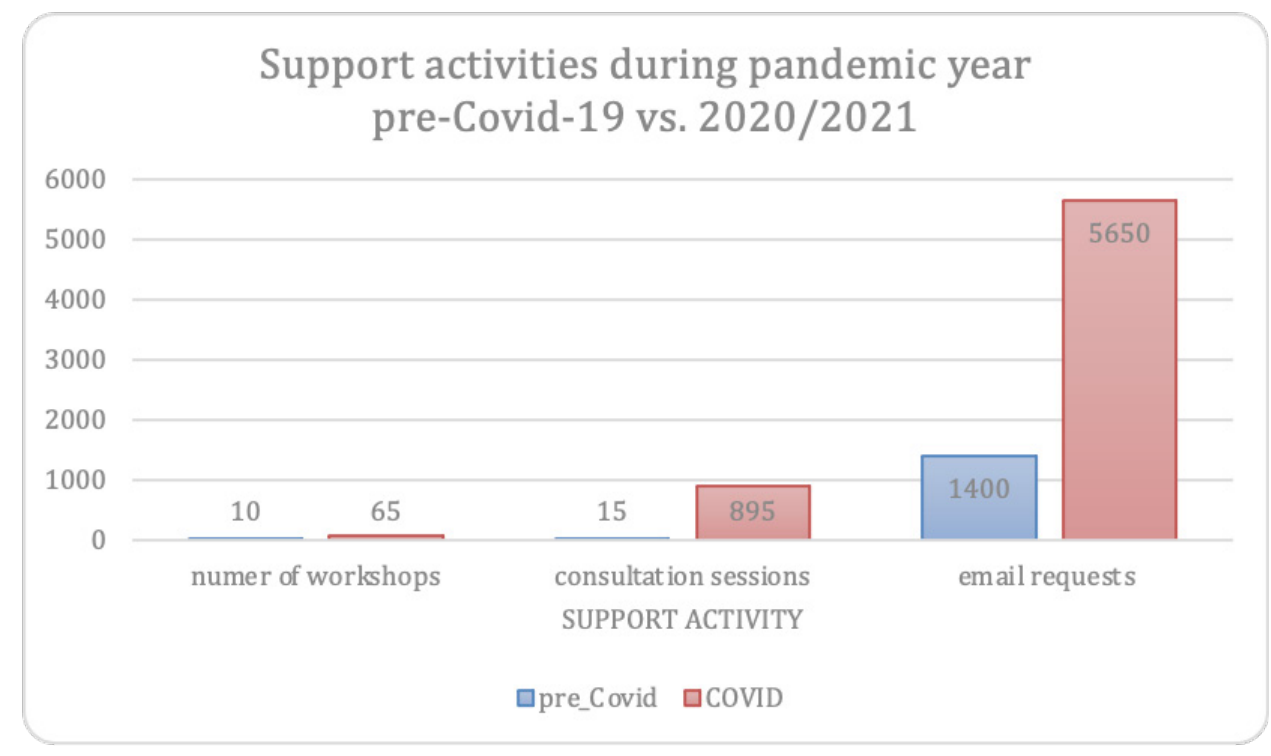

Figure 5. ETS activities before and during covid.

\section{Phase 3: Transformation to hybrid opportunities}

After 18 months of remote work and remote instruction, some institutions, including UBC, announced going back to "normal" in-person teaching in September 2021. Equipped with new skills, instructors, staff, and other members of the university community have started to shift their thinking to how these online spaces could be used in conjunction with in-person teaching. These considerations have led to increased discussions and implementation of hybrid courses. Five different hybrid approaches were identified at the university (CTLT, 2020):
- Concurrent Hybrid: On-campus and remote students attend class synchronously. Instruction and class interactions are livestreamed to allow two-way interaction.

- Asynchronous Hybrid: On-campus instruction is recorded and made available for remote students to access asynchronously at another time (no livestreaming).

- Sequential Hybrid: On-campus and remote students meet in separate, consecutive sessions where instruction is repeated. When students are not in a scheduled class meeting, they are assigned asynchronous work online. 
- Multi-Section Hybrid: Online and oncampus instruction occur in separate sections, potentially taught by different instructors

- Alternating Hybrid: All students are required to attend some on-campus instruction but attend in smaller groups to comply with health guidelines. When not on campus, students engage in learning activities online.

During summer 2021 the AV team worked on enhancing the classrooms, where possible, by adding audio and video devices, building mobile recording kits, and assembling AV Zoom carts that could be booked by instructors. There was still a number of students and faculty members who could not attend classes for various reasons (e. g. international students with issues around visas, vaccination status, immuno-compromised instructors or students), so in preparation for September 2021, ETS had to take into consideration the possibility of all five hybrid models being implemented. The final government financial support for COVID-related expenses was used in the FoE to support the increased hybridity and experimentation with all types of teaching and learning. Graduate students were hired and assigned to hybrid courses to help with the hardware and software available in the classrooms, with booking and handling Zoom carts and mobile recording kits, to facilitate participation of remote students; and work with the ETS team to deliver the synchronous /asynchronous, mostly graduate programs. Number of Teaching Assistants (TAs) increased, as the instructors needed help with hybrid courses "classroom management" and differentiated instruction.

The application of hybrid instruction is not without its own challenges. Not having time to prepare for this new type of teaching, and declaring "hybrid" ad hoc, leaves students not always knowing where their classes are held (online or in the classroom), in what way (synchronous or asynchronous), and how to manage the time between and across the modalities. With re-opening of face-to-face courses for a post COVID-19 university, there has been a continued need to rethink education and instruction in the aftermath of a year of online teaching and learning.

Most courses within the Faculty had a variation of an online course prepared during phase 1 and 2 . This created a unique opportunity for taking advantage of these materials to design personalized courses that use some form of hybrid/blended learning. The BC Ministry of Education went back to the in-person teaching requirements for the Teacher Education program, which reduced the flexibility of instruction for this part of the student population. Despite this, the use of LMS continued, even in its basic, limited form, as a space where students go to find their readings and submit assignments. The commitment for other face-to-face courses to have partial integration of online components have been increasing. Those range from simple use of the LMS, as described with the Teacher Education program, to creating additional opportunities for engagement, such as by using discussions, announcements, and other tools for communication and interaction. In addition, the change in both student and staff perceptions of online learning, its affordances, and the possibilities now play a role in future course design.

\section{Discussion}

Over the year and a half of the initial pandemic response, there was a noticeable shift between different phases in the faculty: remote teaching, designing for online learning, and then re-envisioning instruction to include diverse hybridized models as the faculty move back to in person courses. Looking at the transformations in the way technology was used to support teaching and learning over this time, the phases that emerged nicely align with the SAMR (Substitution, Augmentation, Modification and Redefinition) model (Puentedura, 2010). Substitution occurred at the start of the pandemic through the 
use of online conferencing tools to simulate faceto-face teaching practice. This form of technology integration is at a very basic level and often can be improved since it does not bring additional benefits to the learning. Substitution was fine for an emergency response. During the second phase of pandemic learning design, a process of augmentation and modification occurred through thoughtful consideration of the tools and their affordances to support learning. It is at this juncture in time that there is a possibility of moving forward into redefinition, where technology allows for the creation of new tasks and new ways of thinking about the relationship between teaching, learning and technological tools (Puentedura, 2010).

There were certain advantages to online learning that were noticed by educators and administration such as the flexibility, accessibility, global reach, and equity (Xie et al. 2020). With most of the higher education instructors now having experience in creating or adapting a course for an online environment and teaching online, the standards of what good online teaching is has risen. The student expectation of excellency will be different (Nworie, 2021). What we can expect to see in the near future is a change in institutions' strategic plans and policies in order to respond to those expectations. As Nworie states "universities should develop plans that will guarantee students' readiness to learn online not only in normal times but also in the event of disruptions to classroom instruction, ensuring that there are no roadblocks to synchronous and asynchronous online learning" (2021). The choice of investing in quality design and enhancing faculty digital literacy increases the opportunities for digital transformation (Hodges \& McCullough, 2021).

\section{Challenges and opportunities}

A number of challenges experienced with online education during the pandemic still remain and should be considered as universities move forward.
Each one of them presents both barriers and opportunities. This past year highlighted the importance of digital literacy for faculty, staff, and students. Teachers with previous training in online teaching were better equipped to meet the emergency change to online (Walsh et al., 2021; Times Higher Education, 2021). Universities could take this opportunity to create ongoing training to increase digital literacy skills across faculty and departments. Educational technology support units within universities can play an important role in these professional development programs.

On the other hand, there were a number of systemic problems that surrounded technology. While online teaching provided increased access to students in remote locations or those where being in class physically was problematic, limited access to the Internet and technology by students in lower-income schools or districts during the pandemic widened the existing first-level digital divide (Goldstein, 2020, Scheerder, Deursen, \& Dijk, 2017, Stellmann, Song, \& Tucker, 2021, UNESCO, 2021). How can universities and other educational institutions increase access and accessibility and reduce the increasing divide?

Social isolation and disconnection from inperson engagement had a strong impact on students' well-being (Grajek \& Sobczyk, 2021, Lukács, 2021, Schlesselman, Cain \& DiVall, 2020). The pandemic had negative effects on studies, relationships with family and friends, physical activity, financial situation, health, life satisfaction, and so on. As a consequence, the universities and their academic units, such as FoE, invested in building resources to support students and instructors, and rapidly adopting and implementing tools that support networking and communication (Crawford, 2020, Henrich, 2020). A number of instructors in informal conversations with ETS team members reported higher satisfaction with teaching online when spending more time on getting to know their students better. The pandemic has brought to the forefront the 
values and priorities we, as humans, tend to forget, driven by work, curriculum, deadlines. It has highlighted the need to reshape again the notions of learner-centred design.

The intensive months of remote Zoom classes in summer 2020 demonstrated that synchronous online learning could be extremely exhausting. Zoom fatigue became a concern and with it approaches to creating a better experience as well as what these environments mean for learning (Bailenson, 2021, Hausknecht \& Lim, 2021). The fall and winter semesters in 2020 and 2021 revealed new possibilities with using virtual spaces for learning and the amount of work needed for their design. A mixture of both in-person and online classes in Fall 2021 brought confusion and disorganization demonstrating that we are yet to learn about how to prepare for hybrid. The instructors who are willing to apply the advantages of learning technologies and include the remote participants together with those in the classroom are challenged with inadequate infrastructure, lack of appropriate technology to support differentiated instruction and faced with institutional constraints, such as policies that do not recognize the changed landscape. The traditional 13-week-per-semester classroom course structure is difficult to change despite the existing other models, such as for example, block teaching at the Victoria University in Australia, where Trish McCluskey, the Associate Provost, Learning and Teaching, has been working on building sustainable programmes, applying agile approaches to a radical reconceptualization of the traditional university curriculum since 2018 (Ambler, Solomonides \& Smallridge, 2021). It will take time for institutions to catch up with the new, more fluid and flexible reality. What was learned quickly has to be re-examined, including institutional policies and structures, our own pedagogical paradigms, redefining how we work and learn, and discovering what is sustainable in the long run and what we want our future to be. The changes need to be holistic and systemic.

\section{Limitations and future directions}

This paper outlines the process of a specific educational technology support unit at a university. Thus, the findings are not applicable to every institution world-wide. In addition, the paper is written through the lens of two members of the team. This provided a contextual perspective and indepth knowledge of the process, but it also reflects their views. Future studies could conduct surveys amongst various educational technology support units within the university or across universities to compare their experiences of adapting to the pandemic.

\section{Conclusion}

As we move into a changed reality, it is difficult to determine how the lessons learned over this time will unfold. It is apparent that universities need to be prepared for uncertain events that disrupt traditional approaches and structures. The pandemic has highlighted the importance of having solid systems to support online and hybrid learning. Similar to Adedoyin and Soykan (2020) suggestion, we believe that emergency remote teaching was not ideal (although it was necessary) and universities will consider the lessons learned and move towards more well-designed online courses and hybrid approaches. There is a difference between a quick transition to synchronous learning or designing a course in an extremely limited time with limited readily available resources from a well-planned, full course development process, working with learning designer and tech support staff, with adequate preparation of students to a different way of learning (Nworie, 2021).

During the last year and a half, many institutions have been thrown into a world of online teaching and learning. With the struggles and pitfalls, also comes opportunities to re-envision and re- 
define the role of technology in enhancing teaching and learning. Moving forward, it is up to faculties and institutions to consider what this reshaping will look like for their needs. This is a time when there is an opportunity to embrace innovation and digital literacy promotion for all members of the education environment.

\section{References}

- Adedoyin, O. B. \& Soykan, E. (2020). Covid-19 pandemic and online learning: The challenges and opportunities. Interactive Learning Environments, 1-13.

- Ali, W. (2020). Online and remote learning in higher education institutes: A necessity in light of COVID-19 pandemic. Higher Education Studies, 10 (3), 16-25.

- Ambler, T., Solomonides, I. \& Smallridge, A. (2021). Students' experiences of a first-year block model curriculum in higher education. The Curriculum Journal, 32 (3), 533-558. DOI: 10.1002/curj.103

- Bailenson, J. N. (2021). Nonverbal Overload: A Theoretical Argument for the Causes of Zoom Fatigue. Technology, Mind, and Behavior, 2 (1). DOI: 10.1037/tmb0000030

- Bryson, J. R. \& Andres, L. (2020). Covid-19 and rapid adoption and improvisation of online teaching: curating resources for extensive versus intensive online learning experiences. Journal of Geography in Higher Education, 44 (4), 608-623.

- THE Consultancy (2021). Digital literacy in the UK: Employer perspectives and the role of higher education. Retrieved June 21, 2021. from www: https://www.timeshighereducation.com/academic/

- Crawford, N. (2020). Supporting student wellbeing during COVID-19: Tips from regional and remote Australia. NCSEHE (National Centre for Student Equity in Higher Education). Retrieved July 1, 2021. from www: https://www.ncsehe.edu.au/wp-content/uploads/2020/05/NicoleCrawford-StudentWellbeing-Covid19.pdf

- CTLT (2020). Discussion paper on hybrid teaching and learning. Center for Teaching, Learning and Technology, UBC. Retrieved May 31, 2021. from www: https:/ctlt.ubc.ca/files/2021/01/CTLT_HybridTeachingLearning. pdf

- Goldstein, D., Popescu, A. \& Hannah-Jones, N. (2020). As school moves online, many students stay logged out. The New York Times. Retrieved June 21, 2021 from www: https:/www.nytimes.com/2020/04/06/us/ coronavirus-schools-attendance-absent.html

- Grajek, M. \& Sobczyk, K. (2021). Well-being levels among students during the COVID-19 pandemic. Journal of Physical Education and Sport, 21 (4), 1682-1687.

- Hausknecht, S. \& Lim, S. (2021). Cameras off, Cameras on. Viewpoints Discussion Series, ETS. Retrieved June 10, 2021. from www: https://learningdesignviews.educ.ubc.ca/viewpoints/cameras-on-cameras-off/

- Henrich, K. (2020). Supporting student wellbeing and holistic success: A public services approach. International Information \& Library Review, 52 (3), 235-243.

- Hodges, C. \& McCullough, H. (2021). The Adjacent Possible for Higher Education: The Digital Transformation of Faculty. EDUCAUSE Review, 17, 2021.

- Lukács, A. (2021). Mental well-being of university students in social isolation. European Journal of Health Psychology, 28 (1), 22-29. 
- Rodríguez Núñez, J. \& Leeuwner, J. (2020). Changing courses in midstream: COVID-19 and the transition to online delivery in two undergraduate chemistry courses. Journal of Chemical Education, 97 (9), 2819-2824.

- Nworie, J. (2021). Beyond COVID-19: What's next for online teaching and learning in higher education? EDUCAUSE Review. Retrieved June 10, 2021. from www: https:/er.educause.edu/articles/2021/5/beyondcovid-19-whats-next-for-online-teaching-and-learning-in-higher-education

- Scheerder, A., Deursen, A. V. \& Dijk, J. V. (2017). Determinants of Internet skills, uses and outcomes. A systematic review of the second- and third-level digital divide. Telematics and Informatics, 34 (8), 1607-1624.

- Schlesselman, L., S., Cain, J. \& DiVall, M. (2020). Improving and restoring the well-being and resilience of pharmacy students during a pandemic. American Journal of Pharmaceutical Education, 84 (6), 677-682.

- Stellmann, E., Song, L. \& Tucker, S. (2021). Reexamining digital citizenship: Pandemic lessons to prepare teachers and students for digital learning environments. In: Ferdig, R. E. \& Pytash, K. E. (Eds.). What teacher educators should have learned from 2020 (113-124). AACE-Association for the Advancement of Computing in Education.

- UBC (2021). UBC Research + Innovation. Retrieved August 21, 2021. from www: https://research.ubc.ca/

- UNESCO (2021). Recovering lost learning: what can be done quickly and at scale? Retrieved July 18, 2021. from www: https://unesdoc.unesco.org/ark:/48223/pf0000377841?posInSet=11\&queryId=N-9a6bf9f3f97e-403b-8f60-3460ea7b4632

- UNESCO (2021a). COVID-19: Reopening and reimagining universities, survey on higher education through the UNESCO National Commissions. Retrieved July 18, 2021. from www: https://unesdoc.unesco.org/ ark:/48223/pf0000378174?posInSet=17\&queryId=N-9a6bf9f3-f97e-403b-8f60-3460ea7b4632

- Walsh, L. L., Arango-Caro, S., Wester, E. R. \& Callis-Duehl, K. (2021). Training faculty as an institutional response to COVID-19 Emergency Remote Teaching Supported by Data. CBE - Life Sciences Education, 20 (3), ar34.

- Xie, X., Siau, K. \& Nah, F. F. H. (2020). COVID-19 pandemic-online education in the new normal and the next normal. Journal of Information Technology Case and Application Research, 22 (3), 175-187. 


\section{Наташа Бошкић, Симон Хаускхнехт}

Универзитет у Британској Колумбији, Канада

\section{ПРОМЕНА ОБРАЗОВНОГ ОКРУЖЕЊА: ЗА ВРЕМЕ И ПОСЛЕ ПАНДЕМИЈЕ ВИРУСА КОРОНА}

Циљ овоі̄ раgа је gа ойишемо и анализирамо како је јеgан велики универзииеети у Канаgи оgреаіовао на йочеикку йанgемије вируса корона и касније у йоку йанgемије развијао различитие облике онтајн-насииаве. У раgу се исиитиује йракса тиима за йоgрику образовним

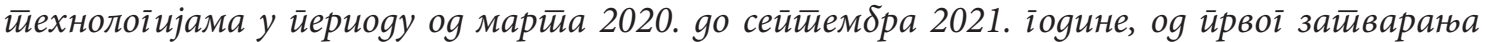

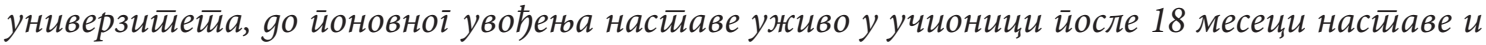
учења на gалину. Промена у настиави и учењу ииоком различитиих фаза йандемије, која је gовела gо gанаште ирроменене стиварностии у образовном окружену, иррвенсиивено се саїлеgава кроз ирризму креаторо учења, на основу юиховоі раgа са насииавницима. У раgу се разматирају оріпнизационе ирромене увеgене збой йойреба насйалих у йоку йанgемије, оgређене

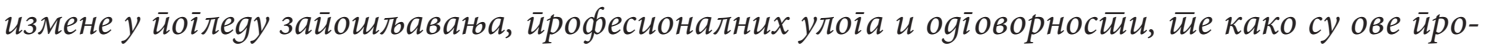

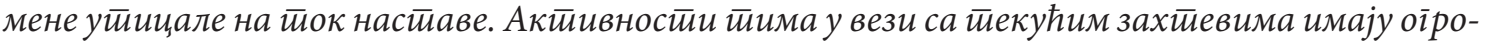
ман уйицај на раяно ойиерећеюе зайослених (нӣр. слаюе мејлова, раяионице, ирилаїођаваюе насииаве у склаgу са новим изазовима).

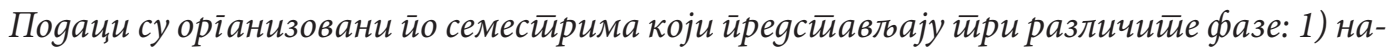
сииава на gатину, 2) искључиво онлајн-настиава, комбинација синхроне и асинхроне настиаве, 3) разноврсни хибрияни йристиуй. Подаци су анализирани йако gа йрецизно оиичиу измене настиле између ових фаза и gа моїу gа се уйореgе разлике. Фазе су сайлеgане йомоћу

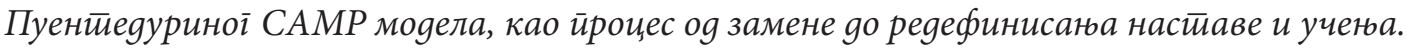

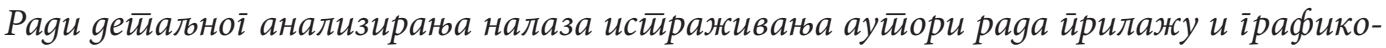
не као визуелну ирреgсииаву иромена у йоіллеgу раяноі ойиерећеюа, анализе оріанизаиионе

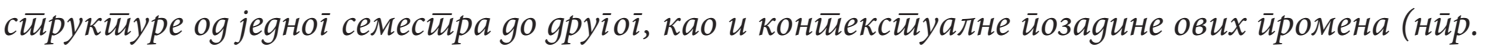

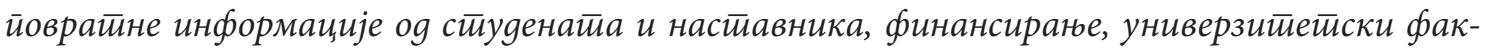

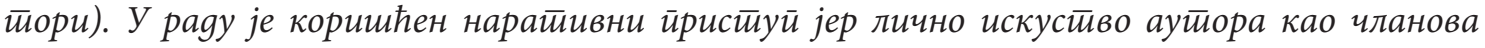

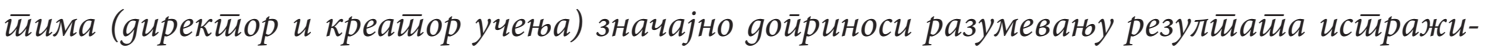
ватьа.

У раяу исииччемо мноїобројне изазове са којима смо се суочили у йоку онлајн-образована за време йандемије. Сваки изазов је исииовремено йрилика и йрейрека. Овим йроцесом

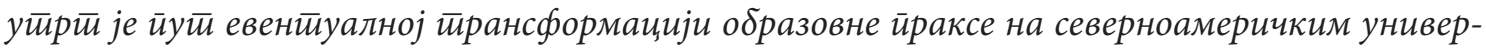

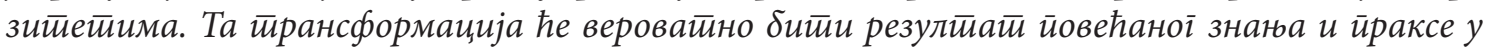

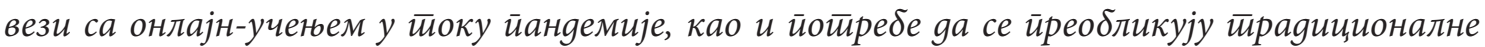

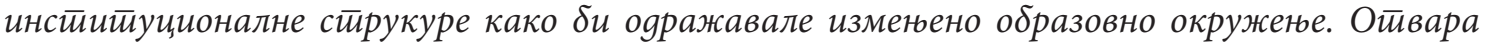
се йростиор за gискусију о јеgнакостии и йристиуйачностии, настиави усмереној на ученика и йоиенцијалу за ирромене у учионици и образовном ирроірамирағуу.

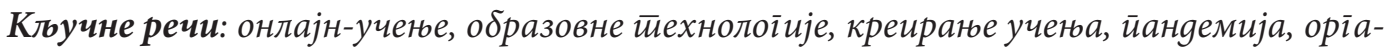
низациона ирромена, йоgрика. 